\title{
Ethno-medicinal Plants Used to Cure Different Diseases by Tribals of Mayurbhanj District of North Orissa
}

\author{
S.D. Rout ${ }^{1}$,T. Panda ${ }^{2}$ and N. Mishra ${ }^{3}$ \\ 1. P.G. Department of Wildlife \& Conservation Biology, North Orissa University, \\ Baripada, Orissa, India \\ 2. Department of Botany, S,N, College, Rajkanika 754 220, Kendrapara, Orissa, India \\ 3. Department of Zoology, Chandbali College, Chandbali 756 133, Bhadrak, Orissa, India
}

KEYWORDS Ethnomedicinal Plants. Modern Healthcare Facilities. Indigenous People. Poverty. Similipal

\begin{abstract}
Mayurbhanj, a hilly district, is rich in ethno medicinal plants. In the present paper 58 plant species belonging to 34 families used in folk medicine have been documented. Due to poor condition of modern healthcare facilities and poverty, indigenous people of the district fully or partially depend on local medicinal plants. An attempt has been made to document traditional knowledge from the baidyas group of Hatikote, Moroda \& Rasgovindpur and Udala \& Kaptipada blocks of Mayurbhanj district on the treatment of various diseases enumerated.
\end{abstract}

\section{INTRODUCTION}

Richness of the biodiversity of Similipal sanctuary in Mayurbhanj district is internationally well acknowledged. Out of around 1076 species recorded so far from Similipal Biosphere Reserve, more than 200 species are attributed with medicinal uses (Rout, 2004). Traditionally Baidyas mostly belongs to tribal communities had been using it to cure their ailments. This system of using herbs and different biological active ingredients in treating various diseases had become a part of their culture till recent years. Entrance of market economy gave rise to exploitation of natural resources and thereby depleting our resources base. The most affected part in this process was medicinal plants, which is most sensitive and delicate in the environment of forest.

Orissa state has one of the oldest and richest cultural traditions of using medicinal plants. The rural people of the state still depend on the traditional ethno medicine for their day-to-day primary health care. These medicinal plants gain further importance in the region where modern medical health facilities are either not available

Corresponding author: T. Panda,

Department of Botony, S. N. College, Rajkanika,

Kendrapara, Orissa, India

Telephone: 9937284680

E-mail: taranisenpanda@yahoo.co.in or not easily accessible. Orissa state is geographically divided into five regions i.e. Coastal Orissa, Southern Orissa, Western Orissa, Central Orissa and North Orissa. The North Orissa is bordering to West Bengal and Jharkhand states. Three districts namely Bhadrak, Balasore and Mayurbhanj includes in North Orissa. In Mayurbhanj district tribes occupy a big chunk of the population constituting $52 \%$ of it and fiftythree communities both aboriginal and migrated are found in the district glorifying the rich heritage of tribal culture (Naik 1998). Among the tribes the chief ones among them are Santal, Kol, Bhomij, Bhuyan, Bathuri, Kharia, Gonds, Mankdias, PauriBhuyan, Saharias, Mahalis and Sounti. Some of these tribes namely Kharias, Mankdias and Saharas are still in primitive state of living. They depend solely on their surrounding forests for most of their requirements from food to medicines.

Although a number of reports are available on ethnobotany of Mayurbhanj district (Bal 1942; Mudgal and Pal 1980; Pandey et al. 2002; Pandey and Rout 2006; Rout and Pandey 2007; Saxena and Dutta 1975; Saxena et al. 1988 and Yogunarasimhan and Dutta 1972) the detailed study on ethno medicinal plants used to cure different diseases by tribals is lacking. Therefore, this paper deals with an attempt to gather information on some traditional uses of medicinal plants from different blocks of the district to document the medicinal uses of plants to cure the common diseases. 


\section{MATERIALS AND METHODS}

The authors have conducted an extensive field survey in the tribal belts and other interior villages adjoining forest areas in the district to collect ethno botanical lore. First hand information was gathered through interactions with tribal and rural people including members of forest protection committees. Further interaction sessions and workshops were held at Udala and Kaptipada and Rasgovindpur and Moroda blocks of this district where local baidyas were also invited to tap the information of medicinal plants commonly used by these traditional healers by questioners. Medicinal properties of plants were learned through informal interviews. A number of group discussions were also conducted during the period of investigation. To ascertain the uses of these medicinal plants the earlier published scientific literature sources referred to are: Sharma et al. (1985-86), Jain (1991), Kirtikar and Basu (1991), Ambasta et al. (1992) and Chopra et al. (1996).

In the following enumeration, plant names have been arranged alphabetically in disease wise. The correct botanical name is followed by family within parentheses, local name in Oriya, the baidyas group of the block, parts use with their medicinal uses.

\section{RESULTS AND DISCUSSION}

Although our ancient sages through hit and trial method developed herbal medicines, the reported uses of plant species do not certify efficacy (Tarafdar 1986). The present preliminary report on ethnomedicinal uses of some plant species need to pharmacologically screened, chemically analysed and tested for bioactive activities (Chandler et al. 1979 and Fairbairn 1980). Pharmacological screening of plant extracts provides insight to both their therapeutic and toxic properties and helps in eliminating the medicinal plants or practices that may be harmful. The study provides information on 58 plant species belonging to 34 families (Table 1). Fabaceae contributed maximum species. Of the plants species described, 2 species are monocotyledons, 41 are dicotyledons, 9 species are herbs, 9 are shrubs, 23 are trees and 15 are climbers.

The plant parts used for medical preparation were bark, flowers, rhizomes, roots, leaves, seeds, gum and whole plants. In some cases the whole plant including roots was utilized. The most frequently utilized plant parts were root (24) followed by the leaves, bark (13) each, seeds (7) and whole plant (6).

The paper presents a brief account of the uses of various ethno medicinal plants parts against the diseases like gastro intestinal disorder, skin diseases, gynaecological disorder, skeletal diseases, jaundice, piles, bronchitis, diabetes, neurological diseases, snakebite, ophthalmic infection and cardiovascular diseases by the people of Mayurbhanj district and highlights the need for further investigation on biochemical and pharmaceutical aspects. The largest number of 16 plant species were used to treat gastrointestinal ailments (constipation, diarrhoea, dysentery, gastric, stomachache), each 10 plant species were used for skin diseases (blood purification, scabies, tumor, itching) and skeletal diseases (pain on limbs, gout, rheumatism, arthritis), 8 plants species each were used for piles and jaundice infection, 6 plant species were used for diabetes and 4 plant species each were treated for gynaecological disorders (gonorrhea, menstrual problems ), respiratory tract infection (bronchitis), snakebite and neurological diseases, 2 plant species each were used for cardiovascular (chest pain) and ophthalmological ailments. Most of the Kaviraj interview were familiar with the species dealing with common ailments like cough, cold, fever and skin diseases.

Some information recorded in the study particularly for Aristolochia indica L., Ficus racemosa L., Hygrophila auriculata K. Schum, Morinda citrifolia L., Pueraria tuberosa (Roxb.ex Willd.)DC. , Soymida febrifuge (Roxb.) A. Juss , and Syzygium cerasoides (Roxb.) Raizada were found to be either not known or little known, where as Andrographis paniculata (Burm.f.)Wall ex Nees, Asparagus racemosus Willd, Hemidesmus indicus (L.)R.Br., Holarrhena pubescens (Buch.-Ham,)Wall ex.G-Don. and Rauvolfia serpentina (L.) Kurz were found to be used very common by other tribes indicating the authenticity of their usefulness ( Saxena et al. 1988 and Sarkar et al. 1999).

The study area is rich in medicinal plant resources. An attempt was made to collect information on the traditional medicinal knowledge present with the local tribes. However, more in depth information may be explored from the tribes residing in the remote blocks of the district. This 


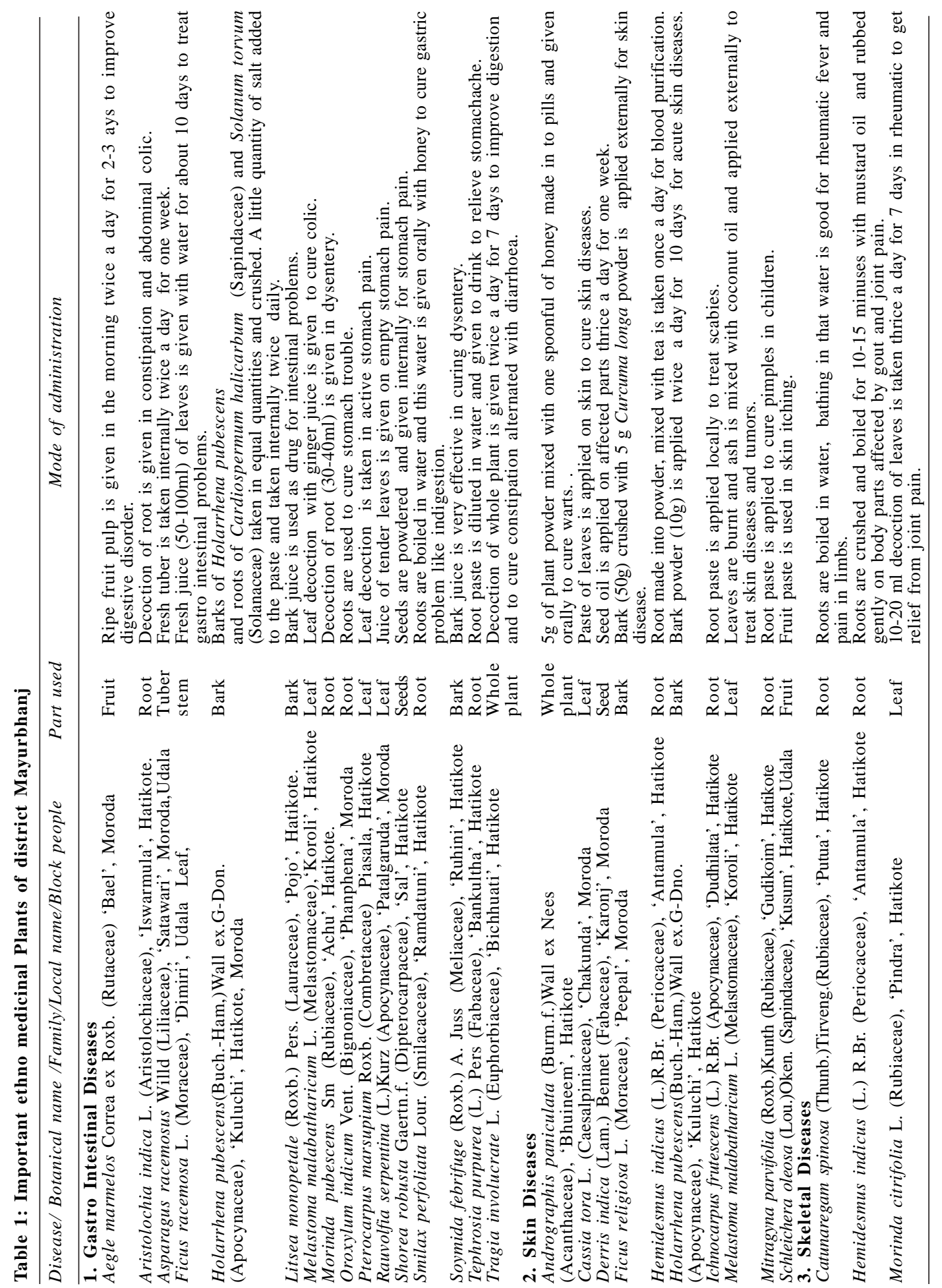




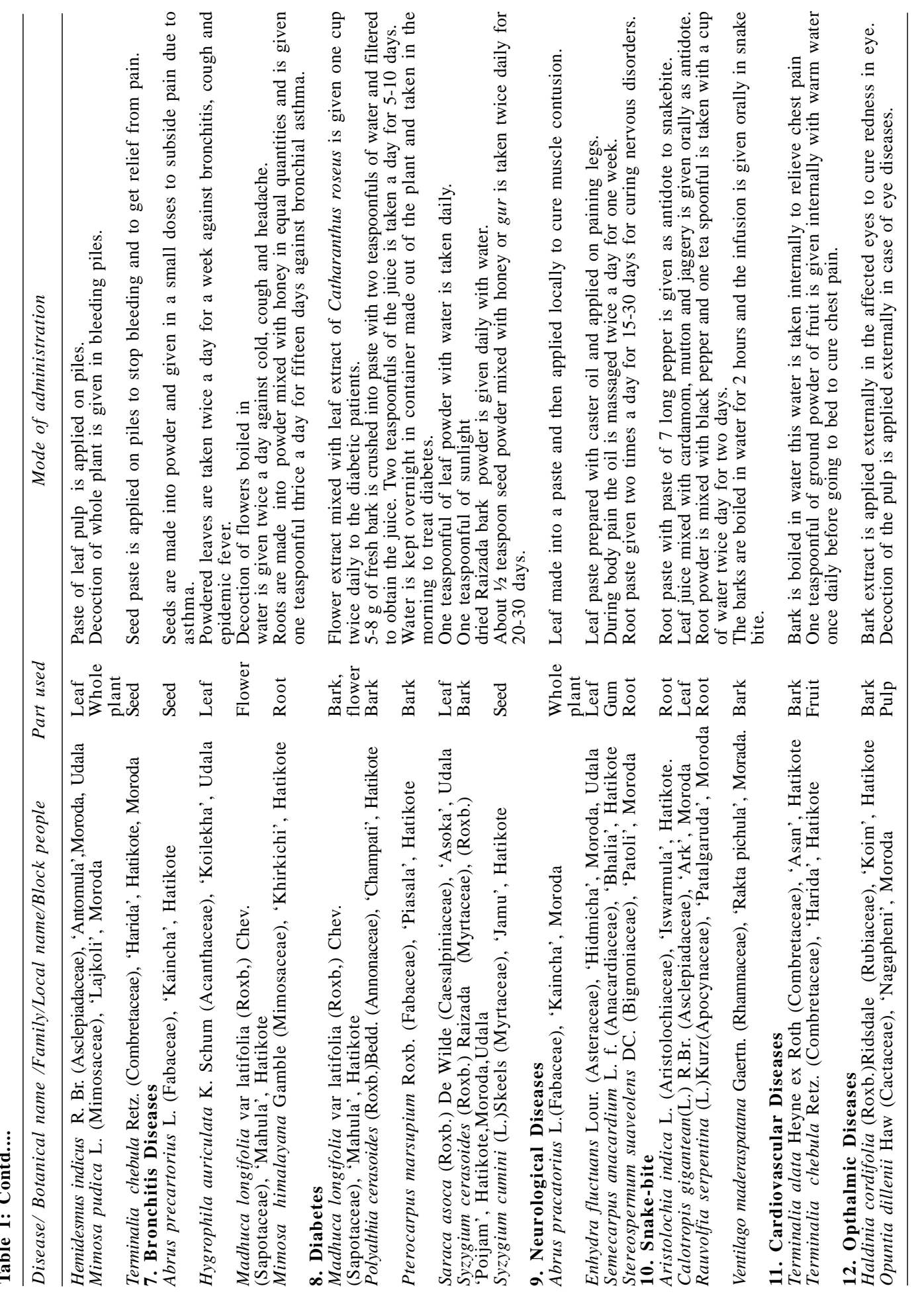


type of study will give new impetus to the traditional system of healthcare. In view of the importance of traditional medicine which provides health services to $75-80 \%$ of the world population, increased demand of herbal drugs by the pharmaceuticals and depleting natural plant resources, it is high time to document the medicinal utility of less known plants available in remote areas of country (Zaidi and Crow 2005).

\section{ACKNOWLEDGEMENTS}

The authors are thankful Dr. D. Swain, Conservator of Forests and Field Director of Similipal Biosphere Reserve, Baripada for his constant encouragement and to the Member Secretary, Orissa State Medicinal Plant Board, Forests and Environment Department, Govt. of Orissa for financial assistance.

\section{REFERENCES}

Ambasta SP, Ram Chandran K, Kashyappa K, Chand R 1992. The Useful Plants of India.New Delhi : Publications and Information Directorate, CSIR .

Bal SN 1942. Useful plants of Mayurbhanj State in Orissa. Rec Bot Surv. India, 6: 1-119.

Chopra RN, Nayar SL, Chopra IR 1996. Glossary of Indian Medicinal Plants. New Delhi: (Repn. Edn.) National Institute of Science Communication. CSIR.

Chandler RF, Freeman L, Hopper SN 1979. Herbal remedies of maritime Indians. J Ethnopharmacol, 1: 49-54.

Fairbairn JW 1980. Perspective in research on active principles of traditional herbal medicines, A botanical approach : identification and supply of herbs. $J$ Ethnopharmacol, 2: 99-106.

Jain SK 1991. Dictionary of Indian Folk Medicine and Ethnobotany. New Delhi: Deep Publications.
Kirtikar KR, Basu BD 1991. Indian Medicinal Plants. 4 Vols. (Repn. Edn). Allahabad: Lalit Mohan Basu Publications.

Mudgal V, Pal DC 1980. Medicinal Plants used by tribals of Mayurbhanj (Orissa). Bull Bot Surv India, 22: 59-62.

Naik D 1998. Tribal culture in the context of Similipal. Workshop Journal on Different Problematic Aspects of Similipal Protection and its Solutary Action Programmes, pp. 63-64.

Pandey AK, Rout SD 2002. Medicinal Plants of Similipal Biosphere Reserve-Perspectives of Plant Biodiversity. In: A.P. Das B Singh, M P Singh (Eds.) Dehra Dun, pp. 681-696.

Pandey AK, Rout SD 2006. Ethnobotanical uses of Plants by tribals of Similipal Biosphere Reserve, Orissa. Ethnobotany, 18: 102-106.

Rout SD 2004. Medicinal Plants of Similipal Biosphere Reserve, Ph. D. Thesis, Bhagalpur: TM Bhagalpur University.

Rout SD, Pandey AK 2007. Ethnomedicobiology of Similipal Biosphere Reserve, Orissa. In: AP Das, AK Pandey (Eds.): Advances in Ethnobotany: Dehera Dun, pp. 247- 252 .

Sarkar N, Rudra S, Basu SK 1999. Ethnobotany of Bangiriposi, Mayurbhanj, Orissa. J Econ Tax Bot, 23(2): 509-514.

Saxena HO, Dutta PK 1975. Studies on the ethnobotany of Orissa. Bull Bot Surv India, 17: 124-131.

Saxena HO, Brahmam M, Dutta PK 1988. Ethnobotanical studies in Similipal Forests of Mayurbhanj District (Orissa). Bull Bot Surv India,10(1-4): 83-89.

Sharma PC, Murthy KS, Bhat AV, Narayanappa D, Prem K 1985-1986. Medicinal-lores of Orissa-I, Skin Diseases. Bull Medico-ethnobot. Res, 6: 93-101.

Tarafdar CR 1986. Ethnobotany of Chhotnagpur, less known and unknown 38 medicinal plants used by the tribals. Folklore, 27: 119-122.

Yoganarasimhan SN, Dutta PK 1972. Medicinal Plants of Orissa- a preliminary survey of Similipal forests, Mayurbhanj District, Orissa. Nagarjun, 15:25-27.

Zaidi MA, Crow SA 2005. Biologically active traditional medicinal herbs from Balochistan, Pakistan. $J$. Ethnopharmacol, 96: 331-334. 